\title{
Hubungan Antar Sifat Jagung Manis yang Dibudidayakan Secara Organik
}

\author{
Traits Association In Sweet Corn as Grown On Organic Cropping System
}

\author{
Eviya Lorenza ${ }^{1}$, Mohammad Chozin ${ }^{2 *}$, Nanik Setyowati ${ }^{2}$ \\ ${ }^{1}$ Dinas Perhubungan, Jl. Lintas Barat, Komplek Sinar Pagi, Kaur, Bengkulu 38563 \\ ${ }^{2}$ Program Studi Agroekoteknologi, Fakultas Pertanian, Universitas Bengkulu \\ *:m_chozin@hotmail.com
}

\begin{abstract}
Capability of growing well under organic conditions is prerequisite for a sweet corn variety to provide high yield under organic cropping management. Therefore, development of high yielding sweet corn varieties for organic cropping system would require sufficient information on the association among the growth traits to facilitate the determination of criteria in the selection program. Objective of this study was to estimate the degree of association among plant growth and developmental traits, in terms of phenotypic and genotypic correlations, in 64 genotypes generated from a complete diallel cross of 8 inbred lines under organic cropping system. Study was conducted from January-March 2016 on Ultisol of Medan Baru, Kandang Limun, sub-district of Muara Bangkahulu, City of Bengkulu at $10 \mathrm{~m}$ above sea level. A randomized complete block design with three replications to allocate the genotypes on double row plots with 4 length and $20 \mathrm{~cm}$ planting space. No agrochemical inputs was applied in cultural practices. Data were collected for plant height,stem diameter, leaf area, leaf number, tasseling date, and silking date. Analysis of variance was performed to determine the significant variation among the genotype. The degree of association among trait was estimated by both phenotypic and genotypic correlations analysis. Analysis of variance showed significant variation for all observed traits. High phenotypic and genotypic correlations were revealed between the growth traits (plant height, stem diameter, leaf area, and leaf number) and between the developmental traits (tasseling date, and silking date). However, the growth traits showed low correlation to the developmental traits.
\end{abstract}

Key words: organic farming, sweet corn, traits

\begin{abstract}
ABSTRAK
Pengembangan varietas jagung manis yang sesuai untuk budidaya organik memerlukan informasi hubungan keeratan antar sifat agar dapat digunakan sebagai dasar dalam penetapan keriteria seleksi untuk meningkatkan daya hasil jagung manis. Seleksi secara langsung terhadap hasil seringkali tidak efektif karena penampilan hasil sangat dipengaruhi oleh lingkungan. Hasil merupakan resultante dari proses pertumbuhan dan perkembangan yang berlangsung selama fase pertumbuhan tanaman. Oleh karena itu, penggunaan sifat-sifat pertumbuhan, perkembangan, dan komponen hasil sebagai kriteria seleksi menjadi pilihan untuk menyeleksi secara tidak langsung untuk peningkatan hasil. Penelitian bertujuan untuk menaksir derajat keeratan antar sifat, baik secara fenotipik maupun genotipik pada tanaman jagung manis yang dibudidayakan secara organik. Penelitian dilaksanakan pada bulan Januari - Maret 2016 di lahan Ultisol Medan Baru, Kelurahan Kandang Limun, Kecamatan Muara Bangkahulu, Provinsi Bengkulu, pada ketinggian tempat 10 m dpl.Penelitian menggunakan Rancangan Acak Kelompok Lengkap dengan perlakuan yang terdiri dari 64 genotipe dan diulang tiga kali. Hasil analisis varian menunjukan, bahwa genotipe yang dievaluasi menunjukkan perbedaan sangat nyata pada seluruh sifat yang diamati yang berarti keragaman yang terdapat dalam populasi dapat dibedakan secara tegas. Secara fenotipik dan genotipik sifat-sifat pertumbuhan (tinggi tanaman, diameter batang, luas daun dan jumlah daun) tidak berhubungan dengan sifat-sifat perkembangan (umur munculnya bunga jantan dan umur munculnya bunga betina).
\end{abstract}

Kata kunci: jagung manis,korelasi, pertanian organik. 


\section{PENDAHULUAN}

Jagung manis (Zea mays saccharata sturt L.) merupakan sayuran berupa tongkol yang dibutuhkan dalam keadaan segar. Jagung manis merupakan komoditas yang disukai oleh masyarakat karena rasanya yang lebih manis dibandingkan dengan jagung pipilan. Selain itu umurnya lebih pendek yaitu antara 70-80 hari (Palungkung \& Budiarti, 2004). Jagung manis juga bisa dimanfaatkan sebagai pakan ternak, kompos, dan batangnya dapat dijadikan sebagai bahan bakar. Jagung manis mengandung karbohidrat, protein, dan vitamin yang tinggi serta kandungan lemak yang rendah (Tangendjaja \& Gunawan, 2000).

Kebutuhan jagung manis yang terus meningkat baik untuk konsumsi segar maupun olahan, serta harganya yang relatif tinggi menjadikan produksi jagung manis harus ditingkatkan (Subandi \& Subachtirodin, 2004). Upaya untuk meningkatkan produksi jagung manis dapat ditempuh melalui penggunaan varietas berdaya hasil tinggi dan dibudidayakan dengan kultur teknis yang tepat, termasuk penggunaan jenis maupun dosis pupuk yang tepat (Rukmana, 1997). Disamping itu penggunaan varietas yang tepat sangat menentukan pertumbuhan dan hasil tanaman. Varietas unggul mempunyai kelebihan dibandingkan dengan varietas lokal dalam hal produksi dan ketahanan terhadap hama dan penyakit, serta respon terhadap pemupukan. Dengan demikian produksi yang diperoleh baik kuantitas maupun kualitas melalui pemeliharaan yang baik masih dapat ditingkatkan (Soegito \& Adie, 1993).

Seiring dengan perkembangan kesadaran masyarakat terhadap produk-produk pertanian yang sehat dan ramah lingkungan telah mendorong berkembangnya pertanian organik. Prinsip dasar dari pertanian organik adalah menghindari penggunaan bahan kimia sintetis (agrokimia) selama proses produksi (Marsono \& Sigit, 2005). Permasalahan yang sering muncul dalam pertanian organik adalah ketersediaan benih tanaman, termasuk jagung manis yang umumnya dimuliakan untuk budidaya secara intensif dengan mengandalkan sarana produksi dari bahan kimia sintetis (Syekhfani, 1993). Dengan demikian, ketersediaan varietas jagung manis yang memiliki daya adaptasi baik pada lingkungan organik akan sangat penting untuk mendukung perkembangan produksi jagung manis secara organik.

Keberhasilan program pemuliaan tanaman dalam mengembangkan varietas baru sangat ditentukan oleh keragaman plasma nutfah yang digunakan dan derajat keeratan antar sifat. Plasma nutfah yang beragam akan memberikan keleluasaan dalam proses seleksi, sedangkan pengetahuan tentang derajat keeratan berguna untuk menentukan sifat-sifat yang dapat diperbaiki secara bersamaan (Jusuf, 1998). Secara genetik, beberapa sifat saling terkait dan diwariskan bersama karena pautan gen (linkage) atau fenomena pleitropi. Pleitropi adalah keadaan yang berhubungan dengan satu faktor atau gen yang berpengaruh terhadap lebih dari satu sifat (Mejaya et al., 2010).

Dalam teknik budidaya, diperlukan informasi hubungan keeratan antar sifat varietas jagung manis yang sesuai untuk budidaya organik. Informasi tersebut dapat dijadikan dasar dalam penetapan kriteria seleksi untuk meningkatkan daya hasil jagung manis. Seleksi secara langsung terhadap hasil seringkali tidak efektif karena penampilan hasil sangat dipengaruhi oleh lingkungan. Hasil merupakan resultante dari proses pertumbuhan dan perkembangan yang berlangsung selama fase pertumbuhan tanaman. Oleh karena itu, penggunaan sifat-sifat pertumbuhan, perkembangan, dan komponen hasil sebagai kriteria seleksi menjadi pilihan untuk me- 
nyeleksi secara tidak langsung untuk peningkatan hasil. Penelitian bertujuan untuk menaksir derajat keeratan antar sifat, baik secara fenotipik maupun genotipik pada tanaman jagung manis yang dibudidayakan secara organik.

\section{METODE PENELITIAN}

Penelitian dilaksanakan di Medan Baru, Kelurahan Kandang Limun, Kecamatan Muara Bangkahulu, Provinsi Bengkulu, pada ketinggian tempat $10 \mathrm{~m}$ dpl, pada bulan Januari - Maret 2016. Penelitian dilakukan melalui percobaan yang melibatkan 64 genotipe jagung manis hasil persilangan dialel dari delapan galur inbrida dengan tiga ulangan dan disusun secara acak dalam Rancangan Acak Kelompok Lengkap (RAKL).

Lahan yang digunakan dibersihkan terlebih dahulu dari vegetasi secara manual dengan menggunakan sabit dan parang sebelum diolah dengan cangkul. Pencangkulan dilakukan untuk membalik tanah dan memecah bongkah tanah agar diperoleh tanah yang gembur untuk memperbaiki aerasi. Tanah yang telah diolah selanjutnya dibagi menjadi tiga blok.

Pemupukan dasar dilakukan satu minggu sebelum penanaman dengan cara menyebarkan pupuk kandang secara merata pada masing-masing blok dengan dosis 10 ton $\mathrm{ha}^{-1}$. Benih ditanam pada lubang yang telah di tugal yang disusun dalam bentuk barisan sepanjang $4 \mathrm{~m}$ dengan jarak antar baris $70 \mathrm{~cm}$ dan jarak tanam dalam barisan $20 \mathrm{~cm}$. Masing-masing genotipe menempati 1 baris yang selanjutnya dianggap sebagai plot percobaan.

Penjarangan dilakukan pada saat tanaman berumur 7 hari ketika tanaman dalam satu lubang tumbuh lebih dari satu. Penyiangan dilakukan dua minggu sekali dengan cara membersihkan gulma secara manual yang tumbuh di sekitar tanaman yang bertujuan untuk mengendalikan gulma yang tumbuh di sekitar jagung manis. Pembubunan dilakukan bersama dengan penyiangan yang bertujuan untuk menggemburkan tanah dan membantu kekokohan tegaknya tanaman serta menambah daerah perakaran tanaman. Beberapa variabel diamati berdasarkan lima tanaman sampel yang ditetapkan secara acak pada saat dua minggu setelah tanam adalah : tinggi tanaman diukur dari pangkal batang hingga ujung daun tertinggi yang telah membuka sempurna, diameter batang diukur dengan menggunakan jangka sorong, jumlah daun dan luas daun diukur pada saat munculnya bunga jantan. Tinggi tanaman, diameter batang, luas daun dan jumlah daun diukur satu kali pada saat munculnya bunga jantan. Variabel lain yang diamati adalah umur munculnya bunga jantan (hst) yang diukur satu kali dihitung sejak tanam hingga munculnya malai dan umur munculnya bunga betina diukur satu kali dihitung sejak tanam hingga munculnya rambut dari tongkol.

Seluruh data yang terkumpul digunakan untuk menaksir hubungan keeratan antar variabel baik secara fenotipik maupun secara genotipik. Secara fenotipik, derajat keeratan diukur berdasarkan taksiran koefisien korelasi sederhana, dengan persamaan (Singh \& Chaudary, 1998).

$$
\mathrm{r}_{\mathrm{p}}=\frac{\operatorname{cov}_{\mathrm{xy}}}{\sqrt{\sigma^{2} x} \cdot \sigma^{2} y}
$$

Hubungan keeratan genotipik diukur melalui penaksiran varians genotipik tiap variabel dan kovarians genotipik antar pasangan variabel berdasarkan rancangan acak kelompok lengkap.

Nilai KT dan HKT pada Tabel 1 dan 2 selanjutnya digunakan untuk menaksir koefisien korelasi genotipik dengan rumus: 
Tabel 1. Analisis varian dan nilai harapan kuadrat tengah

\begin{tabular}{lllll}
\hline $\begin{array}{c}\text { Sumber } \\
\text { Keragaman } \\
(\mathrm{SK})\end{array}$ & $\begin{array}{c}\text { Derajat } \\
\text { Bebas } \\
(\mathrm{db})\end{array}$ & \multicolumn{1}{c}{$\begin{array}{c}\text { Jumlah } \\
\text { Kuadrat } \\
(\mathrm{JK})\end{array}$} & $\begin{array}{c}\text { Kuadrat } \\
\text { Tengah } \\
(\mathrm{KT})\end{array}$ & $\begin{array}{c}\text { Nilai Harapan } \\
\text { Kuadrat Tengah } \\
(\mathrm{NHKT})\end{array}$ \\
\hline Blok & db Blok & JK Blok & KT Blok & $\sigma^{2}{ }^{+}+\mathrm{g} \sigma^{2}{ }_{\mathrm{B}}$ \\
Genotipe & db Genotipe & JK Genotipe & KT Genotipe & $\sigma^{2}{ }^{2}+\mathrm{r \sigma}^{2}{ }_{\mathrm{g}}$ \\
Galat & db Galat & JK Galat & KT Galat & $\sigma^{2}{ }_{e}$ \\
\hline Total & Db Total & JK Total & & \\
\hline
\end{tabular}

Tabel 2. Analisis kovarian dan nilai harapan hasil kali tengah

\begin{tabular}{|c|c|c|c|c|}
\hline $\begin{array}{c}\text { Sumber } \\
\text { Keragaman } \\
(\mathrm{SK}) \\
\end{array}$ & $\begin{array}{c}\text { Derajat } \\
\text { Bebas } \\
(\mathrm{db}) \\
\end{array}$ & $\begin{array}{c}\text { Jumlah Hasil } \\
\text { Kali } \\
(\mathrm{JHK}) \\
\end{array}$ & $\begin{array}{l}\text { Hasil Kali } \\
\text { Tengah } \\
(\mathrm{HKT}) \\
\end{array}$ & $\begin{array}{c}\text { Nilai Harapan } \\
\text { Hasil Kali Tengah } \\
(\text { NHHKT) }\end{array}$ \\
\hline $\begin{array}{l}\text { Blok } \\
\text { Genotipe } \\
\text { Galat } \\
\text { Total }\end{array}$ & $\begin{array}{l}\text { db Blok } \\
\text { db Genotipe } \\
\text { db Galat } \\
\text { db Total }\end{array}$ & $\begin{array}{l}\text { JK Blok } \\
\text { JK Genotipe } \\
\text { JK Galat } \\
\text { JK Total }\end{array}$ & $\begin{array}{l}\text { KT Blok } \\
\text { KT Genotipe } \\
\text { KT Galat }\end{array}$ & $\begin{array}{l}\operatorname{cov}_{e_{x y}}+\operatorname{cov}_{g_{x y}} \\
\operatorname{cov}_{e_{x y}}+\operatorname{rcov}_{g_{x y}} \\
\operatorname{cov}_{\text {exy }}\end{array}$ \\
\hline
\end{tabular}

$$
\begin{gathered}
\mathrm{r}_{\mathrm{G}}=\frac{\operatorname{cov} \mathrm{g}_{(\mathrm{xy})}}{\sqrt{\sigma^{2} \mathrm{~g}_{(\mathrm{x})}} \cdot \sigma^{2} \mathrm{~g}_{(\mathrm{y})}} \\
\sigma_{\mathrm{g}}^{2}=\frac{\text { KT Genotipe-KT Galat }}{3} \\
\operatorname{cov}_{\mathrm{g}}=\frac{\text { HKT Genotipe-HKT Galat }}{3}
\end{gathered}
$$

Keterangan:

rG : koefisien korelasi genotipe

xy

$\operatorname{covg}_{(x y)} \quad:$ kovarians genotip xy

$\sigma_{g(x)}^{2} \quad$ : varians genotipe $\mathrm{x}$

$\sigma^{2}{ }^{2}(y) \quad$ : varians genotipe $\mathrm{y}$

HASIL DAN PEMBAHASAN

\section{Gambaran Umum Penelitian}

Jagung manis tidak tumbuh secara optimal. Hal ini diduga berkaitan dengan jenis lahan yang digunakan untuk penelitian yaitu ultisol yang tingkat kesuburannya rendah. Ultisol merupakan tanah yang mempunyai $\mathrm{pH}$ rendah (4.5) dan Al-dd tinggi yaitu $1.13 \mathrm{me} / 100 \mathrm{~g}$ (Justisia, 2016) serta memiliki karakteristik sifat menyerap air yang rendah (Suriadikarta dan Simanungkalit, 2006). Pemupukan secara berim- bang dan rasional merupakan kunci utama keberhasilan peningkatan produktivitas jagung. Kadar unsur hara di dalam tanah, jenis pupuk/hara yang sesuai, dan kondisi lingkungan fisik khususnya pada agroklimat merupakan faktor penting yang perlu diperhatikan dalam mencapai produktivitas optimal tanaman (Akil dan Dahlan, 2009). Pertumbuhan tidak optimal juga bisa disebabkan oleh dosis pupuk yang digunakan. Pada penelitian ini dosis pupuk yang digunakan adalah 10 ton/ha. Disisi lain penelitian Firlana (2011) menunjukkan, penggunaan pupuk kandang sapi pada dosis 20 ton/ha pada tanaman jagung menunjukkan hasil tertinggi terhadap tinggi tanaman, jumlah daun, jumlah tongkol, berat tongkol, berat basah dan berat pipilan kering, serta berpengaruh terhadap sifat fisik dan kimia tanah. Komposisi unsur hara pada pupuk kandang sapi terdiri atas campuran $0.40 \% \mathrm{~N} ; 0.20 \% \mathrm{P}_{2} \mathrm{O}_{5}$; dan $0.10 \% \mathrm{~K}_{2} \mathrm{O}$.

Selain itu kondisi lahan yang relatif miring menjadi penyebab kurang tersedianya air bagi tanaman sehingga menyebabkan tanaman kekurangan air dan pertumbuhannya tidak optimal. Jagung manis 
merupakan tanaman yang rentan terhadap cekaman air. Hal ini sesuai dengan penelitian Ariyanto dan Sumani (2010) yang menyatakan bahwa ketersediaan air dalam jumlah yang cukup (kapasitas lapang) dalam tanah merupakan indikasi yang sangat baik bagi pertumbuhan jagung manis. Air merupakan penyusun tubuh tanaman (7090\%), bahan baku fotosintesis, pelarut dan medium reaksi biokimia, media transport senyawa, pengatur suhu tanaman dan sebagai tegangan turgor tanaman. Selama penelitian berlangsung terlihat adanya serangan hama pada fase vegetatif yaitu hama belalang yang ditandai adanya lubang-lubang bekas serangan hama pada daun tanaman jagung manis namun kerusakan yang ditimbulkan masih tergolong ringan sehingga tidak dilakukan pengendalian.

Pertumbuhan dan perkembangan tanaman disajikan Tabel 3. Di antara 6 sifat pertumbuhan yang diamati (tinggi tanaman, diameter batang, luas daun, jumlah daun, umur munculnya bunga jantan dan umur munculnya bunga betina), luas daun menunjukkan variasi yang tinggi ( $\mathrm{KK}>25 \%)$ (Gomez \& Gomez, 1984).

Koefisien keragaman (KK) merupakan dispersi relatif yang digunakan untuk membandingkan tingkat variabilitas nilai-nilai observasi suatu data dengan tingkat variabilitas nilai-nilai observasi data lainnya ( Murray \& Larry, 2007). Karena itu, KK juga mencirikan sifat-sifat yang responsif terhadap lingkungan mikro. Sifat yang memiliki KK tinggi cenderung responsif terhadap perubahan lingkungan mikro, atau sebaliknya.

Berdasarkan tinggi tanaman, populasi tanaman yang diteliti memiliki rentang yang sempit dan dengan rata-rata 140.84 $\mathrm{cm}$ maka populasi tersebut dapat dikelompokkan rendah ( Indradewa et al., 2005). Kondisi seperti ini dapat menyebabkan tanaman kekurangan cahaya matahari, tetapi tanaman jagung yang rendah tidak mudah rebah terutama bila ada angin kencang disertai hujan (Salisbury \& Ross, 1995). Diameter batang yang baik berkisar antara 30-40 mm (Warisno, 1998) sedangkan diameter batang yang diteliti berkisar antar 9.40-14.43 mm termasuk dalam kategori kurang baik. Kondisi seperti ini sesuai dengan tinggi tanaman. Tinggi tanaman juga mempengaruhi jumlah daun. Dalam penelitian ini tinggi tanamannya kurang baik sehingga jumlah daunnya juga tidak terlalu banyak (rata-rata 12 helai).

Luas daun pada tanaman jagung sangat dipengaruhi oleh cahaya matahari. Cahaya sangat dibutuhkan dalam proses fotosintesis sebagaimana yang disampaikan oleh Dwidjoseputro (1997) bahwa tanaman butuh cahaya yang lebih banyak untuk proses fotosintesis sebagai sumber energi dan mengolahnya menjadi energi kimia berupa karbohidrat. Luas daun tanaman akan berkaitan dengan kemampuan tanaman dalam menyerap cahaya matahari untuk melakukan aktifitas fotosintesis tanaman. Semakin luas daun maka radiasi matahari yang diterima juga semakin tinggi sehingga fotosintat yang dihasilkan juga semakin banyak. Syarif (2004) menyatakan, luas daun merupakan parameter yang menunjukkan potensi tanaman dalam melakukan proses fotosintesis dan juga merupakan potensi produktif tanaman di lapangan. Luas daun yang baik pada tanaman jagung berkisar 150-600 $\mathrm{cm}^{2}$ (Warisno, 1998) sedangkan rata-rata luas daun yang diteliti adalah $169.58 \mathrm{~cm}^{2}$ yang termasuk dalam kategori baik.

Tanaman akan segera memasuki fase generatif yang diawali dengan pembentukan bunga jantan. Perkembangan bunga jantan akan tumbuh secara optimal apabila tidak terjadinya cekaman. Cekaman fisiologis pada fase perkecambahan dan pertumbuhan vegetatif masih dapat ditoleransi oleh tanaman jagung sebab tanaman jagung termasuk salah satu tanaman yang 
Tabel 3. Nilai rerata, standar deviasi, minimum, maksimum dan koefisien keragaman sifat pertumbuhan dan perkembangan 64 genotipe jagung manis.

\begin{tabular}{lrrrrr}
\hline \multicolumn{1}{c}{ Variabel } & Rerata & $\begin{array}{c}\text { Standar } \\
\text { deviasi }\end{array}$ & Minimum & Maximum & $\begin{array}{c}\text { Kofisien } \\
\text { keragaman (\%) }\end{array}$ \\
\hline Tinggi tanaman (cm) & 140.84 & 2.71 & 134.30 & 147.43 & 0.77 \\
Diameter batang (mm) & 11.72 & 1.06 & 9.40 & 14.43 & 6.14 \\
Luas daun (cm ${ }^{2}$ ) & 169.58 & 74.37 & 142.06 & 1187.00 & 42.57 \\
Jumlah daun (helai) & 11.82 & 1.29 & 9.67 & 21.67 & 8.31 \\
Umur munculnya & 44.16 & 2.05 & 40.00 & 48.67 & 2.74 \\
bunga jantan (hari) & & & & & \\
Umur munculnya & 63.27 & 1.82 & 59.00 & 67.33 & 1.86 \\
bunga betina (hari) & & & & &
\end{tabular}

relatif efisien dalam penggunaan air, sebaliknya cekaman fisiologis pada awal fase generatif akan menunda proses pembentukan bunga betina (rambut tongkol). Hal ini disebabkan pada fase generatif merupakan fase terlemah tanaman jagung terhadap cekaman karena pada masa ini tanaman jagung sedang mengumpulkan energi yang cukup untuk membentuk organ generatif dan penyimpanan makanan (Indrawati, 2004). Pada penelitian ini tanaman jagung manis memasuki fase awal generatif atau munculnya bunga jantan berkisar antara 40-48.87 hari dan munculnya bunga betina berkisar antara 59-67.33 hari.

\section{Analisis Keragaman}

Hasil analisis varian menunjukkan, genotipe yang dievaluasi berbeda nyata pada seluruh sifat yang diamati (Tabel 4). Dengan demikian keragaman yang terdapat dalam populasi dapat dibedakan secara tegas.

\section{Analisis Korelasi Antar Sifat}

Korelasi merupakan suatu ukuran keeratan hubungan antara kedua sifat. Dua sifat dikatakan berkorelasi apabila perubahan sifat yang satu diikuti perubahan pada sifat yang lain secara teratur dengan arah yang sama atau berlawanan (Faizaluddin, 1994).Usman dan Akbar (2000) membuat kriteria keeratan berdasarkan besarnya koefisien korelasi, yaitu tidak berkorelasi $(\mathrm{r}=0)$, berkorelasi sangat rendah $(0.01<\mathrm{r}<0.20)$, berkorelasi rendah $(0.21<\mathrm{r}<0.40)$, berkorelasi sedang $(0.41<\mathrm{r}<0.60)$, berkorelasi tinggi $(0.61<\mathrm{r}<0.80)$, berkorelasi sangat tinggi $(0.81<\mathrm{r}<0.99)$ dan berkorelasi sempurna $(\mathrm{r}=1)$. Nilai koefisien korelasi antar sifat tanaman yang diperoleh sangat berguna dalam menentukan strategi seleksi. Korelasi antara sifat-sifat penting pada 64 genotipe jagung manis yang diteliti disajikan pada Tabel 5 .

\section{Korelasi antar sifat secara fenotipik}

Korelasi antar sifat pertumbuhan (tinggi tanaman, diameter batang, luas daun dan jumlah daun) umumnya rendah hingga tinggi. Tinggi tanaman berkorelasi cukup erat dengan diameter batang $(r=0.870)$, diikuti oleh luas daun $(\mathrm{r}=0.204)$ dan jumlah daun $(\mathrm{r}=0.710)$. Artinya, tanaman yang tinggi akan cenderung memiliki diameter batang yang besar, daun yang luas dan banyak. Hal ini sejalan dengan pernyataan Simanihuruk (2001), bahwa tanaman yang tinggi akan meningkatkan jumlah dan luas daun. Diameter batang berkorelasi cukup erat dengan luas daun $(\mathrm{r}=0.222)$ dan jumlah daun $(r=0.654)$. Sehingga diameter batang yang besar akan cenderung memiliki daun yang luas dan banyak. Jumlah daun tidak berkorelasi dengan luas daun ( $\mathrm{r}$ 
Tabel 4. Hasil analisis keragaman beberapa sifat tanaman jagung manis

\begin{tabular}{lrrr}
\hline \multicolumn{1}{c}{ Sifat tanaman } & KT Genotipe & KT Galat & F hitung \\
\hline Tinggi tanaman & 19.82 & 1.21 & $16.38^{*}$ \\
Diameter batang & 2.28 & 0.52 & $4.39^{*}$ \\
Luas daun & 6191.71 & 5212.88 & $1.19^{*}$ \\
Jumlah daun & 3.02 & 0.96 & $3.14^{*}$ \\
Umur munculnya bunga jantan & 9.77 & 1.46 & $6.67^{*}$ \\
Umur munculnya bunga betina & 7.13 & 1.39 & $5.15^{*}$ \\
\hline
\end{tabular}

Keterangan : ${ }^{*}$ : berbeda nyata pada taraf $5 \%$

tn : tidak berbeda nyata pada taraf $5 \%$

Tabel 5. Korelasi fenotipik antar sifat tanaman dari 64 genotipe jagung manis.

\begin{tabular}{lccccc}
\hline & $\begin{array}{c}\text { Diameter } \\
\text { batang }\end{array}$ & $\begin{array}{c}\text { Luas } \\
\text { daun }\end{array}$ & $\begin{array}{c}\text { Jumlah } \\
\text { daun }\end{array}$ & $\begin{array}{c}\text { Umur muncul } \\
\text { bunga jantan }\end{array}$ & $\begin{array}{c}\text { Umur muncul } \\
\text { bunga betina }\end{array}$ \\
\hline Tinggi tanaman & $0.870^{* *}$ & $0.204^{* *}$ & $0.710^{* *}$ & $0.068^{\text {th }}$ & $0.029^{\text {tn }}$ \\
Diameter batang & & $0.222^{* *}$ & $0.654^{* *}$ & $0.082^{\text {tn }}$ & $0.032^{\text {tn }}$ \\
Luas daun & & & $0.179^{\text {tn }}$ & $-0.081^{\text {tn }}$ & $-0.099^{\text {tn }}$ \\
Jumlah daun & & & & $0.058^{\text {tn }}$ & $0.052^{\text {tn }}$ \\
Umur muncul bunga jantan & & & & & $0.934^{* *}$ \\
\hline
\end{tabular}

Keterangan : **: Berbeda nyata pada taraf $5 \%$

tn : Tidak berbeda nyata pada taraf $5 \%$

$=0.179)$. Dengan demikian daun yang banyak tidak selalu memiliki daun yang luas.

Sifat pertumbuhan (tinggi tanaman, diameter batang, luas daun dan jumlah daun) tidak berkorelasi dengan sifat perkembangan (umur munculnya bunga jantan dan umur munculnya bunga betina) sehingga munculnya bunga jantan dan bunga betina tidak tercermin dari kondisi pertumbuhan tanaman. Sebaliknya umur munculnya bunga jantan dan umur munculnya bunga betina berkorelasi erat dan searah $(\mathrm{r}=0.934)$. Umumnya bunga betina muncul sekitar 20 hari (antara 17-20 hari) setelah munculnya bunga jantan. Hasil penelitian serupa dilaporkan oleh Yuwono et al., (2015) yang menunjukkan bahwa sifat tanaman yang tidak berkorelasi dengan perkembangan adalah tinggi tanaman $(r=-0.04)$ dan sifat yang berkorelasi dengan umur munculnya bunga betina adalah umur munculnya bunga jantan $(\mathrm{r}=0.92)$. Hal ini menunjukkan bahwa sifat-sifat pertumbuhan yang tidak berkorelasi tersebut ti- dak bisa dijadikan sebagai komponen yang penting pada perkembangan jagung manis.

\section{Korelasi antar sifat secara genotipik}

Penaksiran koefisien korelasi mempunyai peran penting dalam menetapkan kriteria seleksi dan menduga kemajuan genetik dari suatu sifat yang diseleksi berdasarkan sifat-sifat yang berkaitan erat dengan sifat tersebut (Falconer, 1981). Ketika sepasang sifat berkorelasi secara genetik maka seleksi terhadap salah satunya akan diikuti perubahan pada sifat yang lainnya (naik/turun sesuai dengan besar kecil dan tanda + atau -) korelasi genetik.

Dalam penelitian ini, taksiran korelasi genotipik dan korelasi fenotipik memiliki arah yang sama (Tabel 6), namun umumnya korelasi genotipik lebih tinggi dibanding korelasi fenotipik. Hal ini berarti bahwa peran faktor lingkungan dalam hubungan antar sifat tersebut sangat kecil.

Falconer dan Mckay (1996) mem- 
Tabel 6. Korelasi genotipik antar sifat tanaman dari 64 genotipe jagung manis.

\begin{tabular}{lccccc}
\hline & $\begin{array}{c}\text { Diameter } \\
\text { batang }\end{array}$ & $\begin{array}{c}\text { Luas } \\
\text { daun }\end{array}$ & $\begin{array}{c}\text { Jumlah } \\
\text { Daun }\end{array}$ & $\begin{array}{c}\text { Umur muncul } \\
\text { bunga jantan }\end{array}$ & $\begin{array}{c}\text { Umur muncul } \\
\text { bunga betina }\end{array}$ \\
\hline Tinggi tanaman & 0.979 & 0.883 & 0.912 & 0.147 & 0.123 \\
Diameter batang & & 0.860 & 0.961 & 0.185 & 0.165 \\
Luas daun & & & 0.218 & -0.399 & -0.453 \\
Jumlah daun & & & & 0.196 & 0.181 \\
Umur muncul bunga jantan & & & & & 0.982 \\
\hline
\end{tabular}

bedakan korelasi fenotipik antar sifat yang menjadi korelasi genotipik dan korelasi lingkungan. Korelasi genotipik disebabkan pleiotropi dan linkage disequibrium. Pleiotropi merupakan peristiwa yang terjadi bila satu gen pada suatu lokus atau pada satu set gen pada beberapa lokus mengendalikan dua sifat yang berbeda atau lebih yang terletak pada kromosom yang sama cenderung diturunkan secara bersamaan. Sebaliknya, korelasi lingkungan terjadi karena lingkungan mempengaruhi tampilan dari dua sifat atau lebih.

Seperti halnya korelasi fenotipik, tinggi tanaman $(\mathrm{r}=0.123)$, diameter batang $(\mathrm{r}=0.165)$, luas daun $(\mathrm{r}=-0.453)$ dan jumlah daun $(\mathrm{r}=0.181)$ secara genetik tidak berkorelasi dengan perkembangan. Demikian juga antar variabel pada fase perkembangan (umur munculnya bunga jantan dengan umur munculnya bunga betina ) berkorelasi erat dan searah $(r=0.982)$. Sehingga dalam program pemuliaan perbaikan sifat pertumbuhan hanya dapat dilakukan melalui sifat pertumbuhan, sedangkan sifat perkembangan hanya dapat dilakukan melalui sifat perkembangan.

\section{KESIMPULAN}

1. Secara fenotipik sifat-sifat pertumbuhan (tinggi tanaman, diameter batang, luas daun dan jumlah daun) tidak berhubungan dengan sifat-sifat perkembangan (umur munculnya bunga jantan dan umur munculnya bunga betina).

2. Secara genotipik sifat-sifat pertumbuhan (tinggi tanaman, diameter batang, luas daun dan jumlah daun) tidak berhubungan dengan sifat-sifat perkembangan (umur munculnya bunga jantan dan umur munculnya bunga betina).

3. Selanjutnya perlu dikaji pola pewarisan sifat-sifat yang berkaitan dengan pertumbuhan dan perkembangan per tanaman sehingga dapat diukur efektifitas seleksi yang dilakukan.

\section{DAFTAR PUSTAKA}

Akil, M. dan H.A. Dahlan. 2009. Budidaya Jagung dan Deseminasi Teknologi. Balai Penelitian Tanaman Serelia. Maros.

Ariyanto, D.P. dan Sumani. 2010. Hubungan Air dan Tanaman. Soil Science Department. Fakultas Pertanian Universitas Sebelas Maret. Surakarta.

Dwidjosaputro. 1997. Pengantar Fisiologi Tumbuhan.Gramedia. Jakarta.

Faizaluddin. 1994. Heretabilitas dan korelasi sifat - sifat kualitas biji beberapa hibrida kakao. Skripsi. Fakultas Pertanian UNIB. Bengkulu. (tidak dipublikasikan).

Falconer, D.S. 1981. Introduction to Quantitative Genetics. $2^{\text {nd }} e d$. Longman, Essex. UK. 
Falconer, D.S dan T.F.C. Mckay. 1996. Introduction to Quantitave. $4^{\text {th }}$ ed. Longman. Har Low, Essex. UK.

Firlana. 2011. Kombinasi kompos sampah kota dan pupuk kandang sapi terhadap sifat kimia tanah inceptisol pada produksi tanaman jagung manis (Zea mays saccharata). Diakses 23 Mei 2016.

Gomez, K.A dan A.A. Gomez. 1984. Statistical Procedures for Agriculture Research. Copyright by John Wiley and Sons. Inc.

Indradewa, D., D. Kastono dan Y. Soraya. 2005. Kemungkinan peningkatan hasil jagung dengan pemendekan batang. J. Ilmu Pertanian 12(2):117-124.

Indrawati. 2004. Saat pemberian air pada jagung. Seminar Hasil Penelitian Tanaman Pangan. LPP Bogor 1:18-23.

Justisia, B. 2016. Perbaikan sifat tanah dan pertumbuhan jagung manis menggunakan kompos eceng gondok. Skripsi. Program Studi Agroekoteknologi Fakultas Pertanian UNIB. Bengkulu. (tidak dipublikasikan).

Jusuf, M. 1998. Genetika I: Struktur dan Ekspresi Gen. Institut Pertanian Bogor. Bogor.

Marsono dan P. Sigit. 2005. Pupuk Akar. Penebar Swadaya. Jakarta.

Mejaya, M.J., M. Azrai, dan R.N. Iriany. 2010. Pembentukan Varietas Unggul Jagung Bersari Bebas. Balai Penelitian Tanaman Serealia. Maros.

Murray, R.S dan Larry, J.S. 2007. Statistik. Erlangga. Jakarta.

c Rukmana, R. 1997. Jagung. Kanisius. Yogyakarta.

Salisbury, F.B. dan C.W. Ross. 1995. Fisiologi Tumbuhan. Jilid I. Edisi IV. ITB. Bandung.
Singh, R. K., and B. D. Chaudhary. 1998. Biometrical Methods in Quantitative Genetics Analysis. Kalyani Publisher. New Delhi.

Simanihuruk, B.W. 2001. Pergeseran gulma pada beberapa jarak tanaman jagung dan pengolahan tanah. Fakultas Pertanian Universitas Bengkulu. Bengkulu.

Soegito dan Adie. 1993. Teknik Bercocok Tanam Jagung. Penerbit Kanisius. Yogyakarta.

Subandi dan Subachtirodin. 2004. .Prospek pertanaman jagung dalam produksi biomas hijauan pakan. Prosiding Seminar Nasional Pemberdayaan Petani Miskin di Lahan Marginal Melalui Inovasi Teknologi Tepat Guna. Mataram 31 Agustus-1 September 2004. hlm 105-110.

Suriadikarta dan Simanungkalit. 2006. Pupuk Organik dan Pupuk Hayati. Balai Besar Penelitian dan Pengembangan Sumberdaya Lahan Pertanian. Bogor.

Syarif, A. 2004. Efek naungan, cendawan mikoriza arbuskula dan pupuk fosfat terhadap pertumbuhan bibit manggis. Sigma 7(3): 259-26.

Syekhfani. 1993. Pengaruh sistem pola tanam terhadap kandungan pupuk organik dalam mempertahankan kesuburan tanah. Seminar Nasional IV Budidaya Pertanian Olah Tanah Konservasi di UNILA. Bandar Lampung.

Tangendjaja, B dan Gunawan. 2000. Jagung dan Limbahnya untuk Makanan Ternak. Balitbang Pertanian Puslitbang Tanaman Pangan. Bogor.

Usman, H dan R.P.S. Akbar. 2000. Pengantar Statistik. Bumi Aksara. Jakarta.

Warisno. 1998. Jagung Hibrida. Kanisius. Yogyakarta. 
Yuwono, P.D., R.H. Murti dan P.S. Basunanda. 2015. Studi keragaman genetik dua puluh galur inbred jagung manis generasi S7. Fakultas Pertanian Universitas Gadjah Mada. Yogyakarta. 